\title{
REVENUE ALLOCATION UNDER THE MRRT: ECONOMIC ASPECTS
}

\section{By Henry Ergas ${ }^{1}$ and Alex Robson ${ }^{2}$}

The Minerals Resources Rent Tax (MRRT) is intended to tax the rents properly attributed to minerals at the time and place of their extraction (ie at the mouth of the mine). However, mining operations involve a degree of vertical integration that in some cases extends from mine to port. We examine the approach adopted in the MRRT to allocating the resulting revenues as between the taxing point and the downstream operations and show that it both lacks economic rationale and is likely to distort build/buy decisions.

\section{INTRODUCTION}

In an earlier paper, Ergas, Harrison and Pincus ${ }^{3}$ argued that the initial Resource Super Profits Tax (RSPT) ${ }^{4}$ was confiscatory and inefficient.

Under the terms of that tax, the federal government would have effectively acquired a 40 per cent equity stake in the existing assets of taxpaying entities, while only paying for that stake at those assets' historical cost. This was not only a retrospective revenue seizure, but also amounted to paying only

\footnotetext{
${ }^{1}$ Professor Henry Ergas, Professor of Infrastructure Economics, SMART Infrastructure Facility, University of Wollongong and Senior Economic Adviser, Deloitte Australia.

${ }^{2}$ Senior Lecturer, Department of Accounting, Finance and Economics, Griffith Business School, Griffith University.

${ }^{3}$ Henry Ergas, Mark Harrison and Jonathan Pincus, 'Some Economics of Mining Taxation' (2010) 29 Economic Papers of the Economic Society of Australia 369 (hereafter 'EHP').

${ }^{4}$ The RSPT, which was originally proposed in May 2010, faced heavy political opposition and was abandoned by the new Prime Minister, Ms Julia Gillard, in July 2010.
} 


\section{REVENUE ALLOCATION UNDER THE MRRT}

for successful 'bets' (at those bets' cost of initial acquisition) while providing no compensation for the many other bets which had not succeeded.

Additionally, the RSPT's carry-forward provisions, which involved an uplift rate for allowable losses based on the government bond rate, effectively assumed that taxpaying entities could treat the promises made by the government of eventually refunding losses as certain. This seemed implausible, given that losses were most likely to crystallise in the event of a downturn in mining, which would place the Commonwealth budget under considerable pressure. Given that one reason for using the allowance for corporate equity $(\mathrm{ACE})^{5}$ model, rather than a pure Brown tax, ${ }^{6}$ was to reduce government cash outlays, it seemed unrealistic to assume that there would be no risk attached to a promise that might substantially increase such outlays at precisely a time of fiscal distress. As a result, the use of the Commonwealth bond rate for the uplift rate placed considerable, uncompensated risk on taxpaying entities.

Lastly, the RSPT was also poorly designed in terms of transition arrangements, with little or no thought given, for instance, to its impact on highly leveraged (ie mostly debt

\footnotetext{
${ }^{5}$ Australia's Future Tax System Review Panel, The Commonwealth of Australia, Report to the Treasurer (2009) at http://taxreview.treasury.gov.au/content/Content.aspx?doc=html/pubs_reports. $\underline{\mathrm{htm}}$ (hereafter the 'AFTS') defines an ACE tax as 'a form of business expenditure tax that provides a deduction (allowance) for corporate equity at the corporate level, equivalent to that provided for interest on debt'; see AFTS, 735. Under an ACE-style tax, project losses can be carried forward at a legislated interest rate (the 'uplift rate') and offset against future profits rather than refunded as they are incurred, which happens are under the pure Brown tax.

${ }^{6}$ See E Carey Brown, 'Business-Income Taxation and Investment Incentives' in Lloyd Metzler (ed), Income, Employment and Public Policy: Essays in Honor of Alvin H. Hansen (W W Norton, 1948) 300. See EHP, above n 1; the Brown tax effectively involves the government taking an equity share in a mining project; under the Brown tax, the government refunds a fraction of the project's cash outlays and receives the same fraction of any cash inflows.
} 


\section{H ERGAS AND A ROBSON}

funded) mining projects which, as explained by $E H P$, would have faced a higher implied tax rate under the RSPT because that tax did not allow for the deductibility of interest payments from assessable revenues.

The Minerals Resources Rent Tax (MRRT), which succeeded the RSPT, was born from negotiations between the three largest mining companies and a newly installed Prime Minister $^{7}$ who, having ousted her predecessor and facing the prospect of an upcoming election, was desperate to secure a deal. As EHP explain, the result was a new tax riddled with distortions and inefficiencies. Their consequences include:

- The use of a single threshold rate for tax liability that will distort investment in the taxable resources (coal and iron ore) away from risky projects and towards less risky projects;

- Taxing those resources while not taxing others will distort investment as between coal and iron ore on the one hand and untaxed resources on the other;

- The tax invites state governments to increase royalty rates, thus exacerbating any inefficiencies those royalties cause, particularly in terms of marginal projects; and

- As the tax amounts to the government acquiring an option on the relevant income streams, the revenues from the tax are likely to prove highly volatile, aggravating the pressures for increased public spending in good times and forcing potentially undesirable reductions in outlays in downturns.

Since then, many of these expectations have been confirmed. For example, both the New South Wales and

\footnotetext{
${ }^{7}$ The broad features of the MRRT agreement was supplemented by the subsequent work of the MRRT Policy Transition Group, which was tasked with consulting with industry and providing advice on the implementation of the MRRT.
} 


\section{REVENUE ALLOCATION UNDER THE MRRT}

Queensland governments have announced increases in coal royalties. Recent media reports have also suggested that the MRRT has not raised any revenue in the first three months of its operation. In addition, the Commonwealth Treasury has estimated the cost of implementing and administering the MRRT (as well as the existing and extended petroleum resource rent tax (PRRT)) at more than $\$ 60$ million over three years. ${ }^{8}$

EHP also noted that the MRRT was based on the assumption that it would be easy to identify the 'rents' that were to be taxed. They stressed that identifying economic rents was by no means a simple undertaking, all the more so given the high degree of vertical and horizontal integration that characterised the major miners.

Since $E H P$, the legislation for the MRRT has been enacted. That legislation confirms EHP's concerns with respect to the MRRT. Indeed, the legislation's approach to identifying economic rents ${ }^{9}$ raises additional problems above and beyond those EHP suggested. These issues arise in the way the legislation requires income to be attributed within vertically integrated mining operations as between upstream activities, ie extraction, which is where the tax is applied, and the downstream activities of transporting and processing the resource.

\footnotetext{
${ }^{8}$ See Sid Maher, 'Resource taxes 'cost more than they raise', The Australian (Sydney) 12 December 2012. Alex Robson, On the Volatility of Resource Rent Tax Revenue (Background Paper, Minerals Council of Australia, 2012), available at:

http://www.minerals.org.au/file_upload/files/publications/mca_volatility_of_re source_rent_tax_revenue_FINAL.pdf, shows that the revenue from the Petroleum Resource Rent Tax (which applies to oil and gas but shares a number of the MRRT's design features) has been highly volatile since its introduction in the late 1980s.

${ }^{9}$ An economic rent can be defined as the difference between what a factor of production is paid and how much it would need to be paid to remain in its current use; see Matthew Bishop Essential Economics (Bloomberg Press, 2004).
} 


\section{H ERGAS AND A ROBSON}

It is not the purpose of this paper to consider alternative approaches to mining taxation, but to examine the implementation issues arising in the MRRT, notably with respect to revenue allocation and the distortions this is likely to create. In examining those distortions, we proceed as follows. We start by discussing what the MRRT (according to the legislation) is attempting to tax, which is essentially the rent associated with the resource at the point of extraction. We then show that the approach adopted in the legislation could result in its taxing not merely that rent, but any real or apparent supranormal income associated with selling the mined resource, including the income derived from superior efficiency. This arises from the requirement to impute all such income to the upstream, or taxing, point, where it becomes liable to MRRT. We contrast that outcome with that which would occur under bargaining between upstream and downstream entities, where each entity brings some unique contribution to the joint enterprise. A final section concludes.

\section{WHAT IS THE MRRT TRYING TO TAX?}

In principle, according to Section 1-10 of the MRRT Act, ${ }^{10}$ the MRRT is intended to tax: '.. above normal profits made by miners (also known as economic rents) that are reasonably attributable to the resources in the form and place they were in when extracted'.

In practice, the economic rents 'reasonably attributable to the resources in the form and place they were in when extracted' are unobservable; rather, the observable elements are the revenues and outlays associated with the sale of the resources being taxed.

In turn, those revenues and the associated outlays result from a highly vertically integrated, technologically complex

${ }^{10}$ Mineral Resource Rent Tax Act 2012 (Cth) (the 'MRRT Act'). 


\section{REVENUE ALLOCATION UNDER THE MRRT}

process that stretches from extraction at the mine to sea-borne transport and includes both a wide range of physical transformations and of planning, financing, marketing and management control activities required for the efficient undertaking of the physical transformations. ${ }^{11}$

As a matter of economics, the net cash flows generated by this complex of activities could include two sources of resource rents, as conventionally defined.

The first are rents associated with the exhaustible nature of the resources; these are Hotelling rents ${ }^{12}$ that reflect the gap between price and marginal cost that arises because the opportunity cost of extraction today is foregone extraction at a time closer to resource depletion. The second are rents associated with differential resource efficiency, the classic Ricardian rents $^{13}$ that reflect differences between mines in factors such as extraction costs and proximity to resource users.

In practice, for reasons explored in the literature on resource economics, it is likely that the Hotelling rents are small or nonexistent. $^{14}$ Ricardian rents are more likely to exist, but their quantum is highly uncertain. Moreover, both Hotelling and Ricardian rents are time-varying, as technological change and shifts in intermediate and final demand change their quantum, adding to the difficulties involved in determining their value in each taxable period.

\footnotetext{
${ }^{11}$ Henry Ergas 'An Excess of Access: An Examination of Part IIIA of the Australian Trade Practices Act' (2009) 16 Agenda: A Journal of Policy Analysis and Reform 37.

12 See Harold Hotelling, 'The Economics of Exhaustible Resources' (1931) 39 Journal of Political Economy 137.

${ }^{13}$ See David Ricardo, On the Principles of Political Economy and Taxation (John Murray, $3^{\text {rd }}$ ed, 1817).

${ }^{14}$ John Tilton, On Borrowed Time? Assessing the Threat of Mineral Depletion (Resources for the Future Press, 2003).
} 


\section{H ERGAS AND A ROBSON}

However, these resource rents plainly do not exhaust the potential sources of supra-normal earnings to mining operations. Three points are especially important in this respect.

First, to the extent to which firms differ in the technology that they use and other dimensions of efficiency, the more efficient firms will earn rents due to their superior efficiency. That superior efficiency can reflect a number of factors, including entrepreneurship and special skill in amassing and deploying scarce resources such as managerial talent. In turn, those factors translate into a combination of unusually low costs (both because of economies of scale and scope, and because of higher efficiency at each point on the cost curve) and aboveaverage consumer willingness to pay (for instance, because of especially high quality assurance or reliability). To that extent, the firm's cost curve shifts down and to the right, while the demand curve it faces shifts out and also to the right.

While supra-normal earnings arising from these sources are sometimes described as Schumpetarian (reflecting the emphasis Schumpeter placed on their importance as an inducement to technological progress and hence economic growth),${ }^{15}$ they are for our purpose better described as Bertrand rents in the sense that, given differential efficiency, they would arise even in a large numbers, competitive auction for the right to exploit the resource. $^{16}$

\footnotetext{
${ }^{15}$ See Joseph Schumpeter Capitalism, Socialism and Democracy (Harper Perennial, $3^{\text {rd }}$ ed, 1962).

${ }^{16}$ See Joseph Bertrand, 'Review of Theorie mathematique de la richesse sociale and of Recherches sur les principles mathematiques de la theorie des richesses' (1883) 67 Journal des Savants 499. In an auction with a very large number of ex-ante identical bidders, the seller will tend to obtain most of the gains from trade. This happens because the large number of buyers will compete fiercely and bid away any gains from trade that they might otherwise have received. However, if bidders to mining rights have different valuations due to different technological abilities or costs, then bidders with lower mining costs will enjoy some positive gains from trade (ie profits) even when there are large number of other, high cost bidders.
} 


\section{REVENUE ALLOCATION UNDER THE MRRT}

Second, and by contrast, the firm may earn supra-normal profits not from superior efficiency but from market power. That market power may either attach to ownership of an individual resource or, more usually, to ownership of a portfolio of substitutable resources. Moreover, it may be unilateral (in the sense that price will be above marginal cost even if the firm acts independently of other firms) or concerted (in the sense that price is driven above marginal cost by the choice of a strategy that is individually rational only to the extent to which it is adopted by a grouping of firms, as in tacit collusion). Clearly, unlike Bertrand rents, these rents would not arise in a competitive large numbers auction for the right to exploit the resource.

Third and last, in both cases (Bertrand rents and rents from market power), there are significant difficulties involved in trying to tease apart rents from quasi-rents.

In particular, Bertrand rents may, and likely usually do, simply reflect capitalised cash flows from innovation, where the apparently high rate of return is merely the result of the riskiness investing in innovation involves.

Equally, and very importantly in the case of the taxpayers covered by the MRRT, where capacity augmentation is lumpy and involves high sunk costs, gaps between prices and marginal costs will be required to induce investment. ${ }^{17}$ This is because those gaps signal the shadow price of capacity constraints and it is the height of that shadow price, compared to the cost to the firm of extinguishing the option to postpone investment, that determines the optimal timing of investment - see Box A for a simple example.

\footnotetext{
${ }^{17}$ See, for example, Avinash Dixit, Robert Pindyck and Sigbjørn Sødal, 'A Markup Interpretation of Optimal Rules for Irreversible Investment' (Working Paper No 5971, NBER , 1997), who show that the optimal investment rule has exactly the same form as the formula for a firm's optimal markup of price over marginal cost.
} 


\section{H ERGAS AND A ROBSON}

To that extent, taxing these seemingly supra-normal earnings is inherently distorting. Moreover, those distortions are likely to be large compared to the effects of royalties. This is because royalties have an adverse effect on output at the margin, but at least at the royalty rates that have been common in Australia, the affected output accounts for a small share of total output. Moreover, the output that is suppressed is the output on which cash returns are lowest. As a result, the social loss ${ }^{18}$ from suppressing it - that is, the foregone surplus - is small, at least for royalty rates at levels commonly observed in Australia. ${ }^{19}$

In contrast, a tax that reduces the incentives to innovate and that distorts the optimal timing of capacity expansion will induce a first-order efficiency loss, as it will reduce social surplus $^{20}$ on the bulk of taxed output. Given that, the way the MRRT actually proposes to define the taxed income is crucial. It is to this approach that we now turn.

\section{THE MRRT'S APPROACH}

In essence, for each taxable project, the MRRT proposes to allocate all the income above the allowed rate of return on the opening capital base to the "the resources in the form and place they were in when extracted'. ${ }^{21}$ In particular, it assumes that any income above the MRRT

\footnotetext{
${ }^{18}$ Broadly speaking, the social loss or excess burden of a tax is the reduction in overall net economic benefits caused by the tax once revenue is taken into account. See Robson, above $\mathrm{n} 8$.

${ }^{19}$ AFTS, above $\mathrm{n} 5$, claimed that royalties were highly distorting. For example, Chart 1.5 on page 13 of the AFTS suggests royalties have marginal deadweight loss per dollar of revenue of 70 per cent. However, some serious questions about the modeling have been raised in Harold Ergas and Jonathan Pincus, 'Modelling the Excess Burden of Royalties' (School of Economics Working Papers 2012-03, University of Adelaide, 2012).

${ }^{20}$ As measured by the difference between aggregate economic benefits and aggregate economic costs of the activity.

${ }^{21}$ See MRRT Act, s 1-10.
} 


\section{REVENUE ALLOCATION UNDER THE MRRT}

carry-forward rate of return is attributable to the resource, rather than to the other factors discussed above.

Central here are the provisions that seek to allocate net revenue within vertically integrated mining firms, that is, firms that operate both upstream, extractive operations and downstream, transformative operations (such as blending, transport and loading). The revenue stream to those firms obviously reflects the combined upstream and downstream inputs. As the MRRT applies to the upstream revenue, the determination of the division of the joint revenue between upstream and downstream has an obvious impact on the extent of the tax liability.

Section 30-25(3) of the MRRT Act requires the use of a method that "produces the most appropriate and reliable measure of how much of the revenue amount is reasonably attributable' to the taxable resource. Section 30-25(4) states that in using such a method, a number of assumptions must be made 'to the extent they are relevant to the method.' Assuming the statutory assumptions are relevant, the MRRT Act also sets out in s 30-25(4) two crucial elements to be adopted in effecting this revenue division. The first is the requirement that the upstream and downstream be treated as if they were separate entities, operating at arm's length ('that ... deal wholly independently with one another' ${ }^{22}$. The second is that the downstream entity must be assumed to operate in a market that is competitive in the sense that the returns to the notional downstream entity would be no more or less than are necessary for it to commit capital, and in particular are

${ }^{22}$ Ibid s 30-25 (4)(c). 


\section{H ERGAS AND A ROBSON}

commensurate with the non-diversifiable risks inherent in the things it does.' 23

The legislation does not specify precisely how these assumptions should be implemented. However, obvious problems arise in their implementation. For instance, to the extent to which the entities were in fact 'wholly independent', they could not achieve the efficiencies of vertical integration that the integrated firm achieves). ${ }^{24}$ As a result, costs would be higher and output lower in this counter-factual than they are in reality, hence reducing the taxable income. Alternatively, if it assumed that those economies are achieved nonetheless, the MRRT, were it to allocate the entirety of any gains on those economies to the upstream entity, would act as a tax on achieving the economies of vertical integration, thus inappropriately taxing income that is not a mineral rent.

Nor is the tax entirely hypothetical; if the firm was not in fact vertically integrated, the legislation would allow revenues to be allocated as between the upstream and downstream entities as they are in reality. As a result, a currently vertically integrated entity could be better off divesting its downstream operation. While foregone efficiencies of vertical integration would lower the value of the firm, the reduced MRRT tax liability could be more than sufficient to offset that loss.

This highlights a wider point: allocating the entirety of the supra-normal profit to the upstream operation will reduce the incentive to seek Bertrand and market power rents. Any loss of Bertrand rents is a pure loss in social

${ }^{23}$ Ibid s 30-25 (4)(d)(ii).

${ }^{24}$ See Ergas, above n 11. 


\section{REVENUE ALLOCATION UNDER THE MRRT}

efficiency and, as the market power rents are largely if not entirely paid by foreign consumers, ${ }^{25}$ discouraging firms from securing those rents will reduce the income to Australia.

The possible harm does not end there. In effect, the Act allows the taxpaying entity to select as a safe-haven option for determining its MRRT liability an approach in which the downstream entity is treated as if it were a rate of return regulated firm, ie a firm that was constrained to earn, ex post, its regulated cost of capital. However, this inevitably invites inefficiencies. These include factor price distortions - notably Averch-Johnson effects, ${ }^{26}$ which involve distortions to capital intensity, the capacity/output ratio and the timing of investment - as well as reductions in the incentives for the firm to reveal and act on private information about opportunities for cost reduction.

These weaknesses were not present in the first exposure draft of the MRRT legislation. ${ }^{27}$ In its section 19-25(2), that draft simply referred back, at least implicitly, to general transfer pricing principles. In doing so, it was consistent with the final report of the MRRT Policy Transition Group ${ }^{28}$ which, in endorsing the use of

\footnotetext{
${ }^{25}$ Since the vast majority of coal and iron ore mined in Australia is exported overseas, foreign consumers bear most of the incidence of higher prices. ${ }^{26}$ See Harvey Averch and Leland Johnson, 'Behavior of the Firm Under Regulatory Constraint' (1962) 52 American Economic Review 1053. The Averch-Johnson effect refers to the tendency of a firm whose rate of return on capital is regulated to respond these regulatory incentives by choosing a distorted capital/labour ratio, which is too high for its chosen level of output. ${ }^{27}$ See Minerals Resource Rent Tax Bill (First Exposure Draft) 2011 (Cth) at. http://archive.treasury.gov.au/documents/2070/PDF/Exposure\%20Draft\%20Bi 11\%20-\%20Minerals\%20Resource\%20Rent\%20Tax.pdf.

${ }^{28}$ See Policy Transition Group, Policy Transition Group Report to the Australian Government: Mew Resource Taxatio Arrangements (Australian
} 


\section{H ERGAS AND A ROBSON}

the OECD Transfer Pricing methods, stated (at page 32) that in allocating revenue within the integrated entity 'widely understood (transfer pricing) concepts and methodologies, including OECD profit methods, must be considered' (emphasis added). Those OECD profit methods referred to by the Policy Transition Group would have split economic profits as between the upstream and downstream entities, rather than allocating the entirety of those profits to the upstream entity.

\section{ALTERNATIVE APPROACHES}

For the reasons discussed above, allocating the entirety of apparent rents to the upstream activity is likely to be highly distorting. Yet there is no reason to think this is indeed the outcome that would prevail were there in fact independent bargaining between an upstream and a downstream entity each of which had unique assets, say of managerial know-how, and where there were gains from cooperation to be divided between those entities.

Thus, economists generally view the problem of allocating gains from cooperation between bargaining entities through the prism of the theory of cooperative games. Since at least $1990,{ }^{29}$ it has been standard to use that theory to analyse issues of resource allocation to cooperating factors within the firm. ${ }^{30}$

The cooperative game-theoretic approach views the firm as a coalition that forms between various inputs. It generally treats the allocation of joint revenue to those inputs as a problem to be

Government, December 2010)available at http://www.taxwatch.org.au/ssl/CMS/files_cms/186_MRRT\%20Report.pdf. ${ }^{29}$ Oliver Hart and John Moore, 'Property Rights and the Nature of the Firm' (1990) 98 Journal of Political Economy 1119.

${ }^{30}$ See, for example, Oliver Hart, Firms, Contracts and Financial Structure (Clarendon Press, 1995) and Raghuram Rajan and Luigi Zingales, 'Power in a Theory of the Firm' (1998) 113 Quarterly Journal of Economics 387. 


\section{REVENUE ALLOCATION UNDER THE MRRT}

solved axiomatically, ie by identifying an allocation algorithm (or solution concept) that meets certain, a priori reasonable characteristics. By far the most important of these solution approaches is the Shapley value, ${ }^{31}$ in which each input receives its average marginal contribution, assuming that each arrangement or permutation of activities is equally likely. ${ }^{32}$

The Shapley value always exists, is unique and can be justified both axiomatically ${ }^{33}$ and as the solution to a noncooperative game. ${ }^{34}$ Moreover, the so-called Value Equivalence Theorem $^{35}$ states that as the number of players becomes large, the Shapley value coincides with the outcome that would obtain in a perfectly competitive market.

The general formula for the Shapley value can be derived as follows. Suppose that there are $\mathrm{N}>1$ entities. If all cooperate together, they generate a value of $v(N)$. A subset $\mathrm{S}$ of the grand coalition $\mathrm{N}$, which has $\mathrm{s}$ members, generates a value of $v(S)$. Let $\{\mathrm{i}\}$ be the subset in which the input $\mathrm{i}$ produces alone. The marginal contribution of input $i$ to the coalition $S$ is $[v(S)-v(S-\{i\})]$.

\footnotetext{
${ }^{31}$ See Lloyd Shapley, 'A Value for n-person Games' in Harold Kuhn and Albert Tucker (eds), Contributions to the Theory of Games Vol II (Princeton University Press, 1953) 307. Lloyd Shapley was the recipient of the 2012 Sveriges Riksbank Prize in Economic Sciences in Memory of Alfred Nobel. His 1953 paper was specifically cited by the Nobel committee in its background paper on the award; see http://www.nobelprize.org/nobel_prizes/economics/laureates/2012/advancedeconomicsciences2012.pdf.

${ }^{32}$ Hervé Moulin, Fair Division and Collective Welfare (MIT Press, 2003).

${ }^{33}$ Hervé Moulin, Axioms of Cooperative Decision-Making (Cambridge University Press, 1988).

${ }^{34}$ Faruk Gul, 'Bargaining Foundations of Shapley Value' (1989) 57 Econometrica 81 .

${ }^{35}$ See, for example, Sergiu Hart, 'Values of Perfectly Competitive Economies' in Robert Aumann and Sergiu Hart (eds) Handbook of Game Theory with Economic Applications Vol III (North Holland, 2002) Chapter 57.
} 


\section{H ERGAS AND A ROBSON}

Now, there are (N-s)! ways in which the members outside $\mathrm{S}$ could form, and (s-1)! ways in which the members of $S$ could form without the input $\{i\}$. Hence the number of ways in which \{i\} can make a marginal contribution of $[v(S)-v(S-\{i\})]$ is $(N-s) ! \times(s-1)$ !, and the probability of $\{\mathrm{i}\}$ making this contribution is simply $(N-s) ! \times(s-1) ! / N$ !.

Hence the expected or average marginal contribution of $\{i\}$, which is i's Shapley value, is: ${ }^{.3}$

$$
\varphi_{i}[v]=\sum_{S \subset N, i \in S} \frac{(N-s) !(s-1) ![v(S)-v(S-\{i\})]}{N !}
$$

Rosenthal $^{37}$ and the references therein apply the Shapley value to the problem of transfer pricing within a vertically integrated firm. A simple hypothetical numerical example of how the Shapley value could be applied to the allocation of net income within a vertically integrated mining firm is provided in Box B.

The more general point is that if a downstream participant in a bargaining game had unique cost advantages, it would secure a return on those advantages; however, it is at best unclear whether this would occur under the approach mandated by the MRRT.

On the one hand, even in a competitive market, Bertrand rents will accrue to the party with the information required to achieve those unique or differential efficiencies; to that extent, even in a competitive market benchmark, where securing those efficiencies relies on information that is private information to

\footnotetext{
${ }^{36}$ See, for example, Andreu Mas-Colell, Michael Whinston and Jerry Green, Microeconomic Theory (Oxford University Press, 1995) 682.

${ }^{37}$ Edward Rosenthal A Game-Theoretic Approach to Transfer Pricing in a Vertically Integrated Supply Chain' (2008) 115 International Journal of Production Economics 542.
} 


\section{REVENUE ALLOCATION UNDER THE MRRT}

the downstream entity, it is the downstream entity that would earn the apparent supra-normal returns, even in such a competitive market. On the other hand, the language of section 30-25(4), though it invokes the benchmark of a competitive market, specifies that the rate of return to the notional downstream entity must be no more or less than is necessary for it to commit capital. This obviously places the burden of determining the income allocation on the setting of that allowed rate of return.

This in itself, however, is not truly determinative of the income allocation. This follows from applying the standard Laffont-Tirole ${ }^{38}$ model of procurement to a firm contracting out the downstream activity in a market with a large number of suppliers but where each potential supplier has private information about production costs. In that instance, the upstream firm will allow the winning bidder an information rent that reflects inter alia the extent of the information asymmetry between the upstream and the downstream entities. ${ }^{39}$ To the extent to which the resulting optimal contract is treated as the reference point for the income allocation under the MRRT, downstream rents would remain where they sit.

It is equally clear that there is a degree of tension between this outcome and the result being sought by the legislation. This is apparent from the fact that while the initial exposure draft, consistent with the Policy Transition Group report, ${ }^{40}$ was reasonably non-prescriptive, the final legislation went to some lengths to attempt to ensure all income above the allowed carryforward rate was imputed to the upstream activity. However, for all the reasons set out above, it is an open question whether it

\footnotetext{
${ }^{38}$ See Jean-Jacques Laffont and Jean Tirole, A Theory of Incentives in Procurement and Regulation (MIT Press, $2^{\text {nd }}$ ed, 1993).

${ }^{39}$ See, for example, Farid Gasmi et al, Cost Proxy Models and Telecommunications Policy: A New Empirical Approach to Regulation (MIT Press, 2002).

40 Above $n 28$.
} 


\section{H ERGAS AND A ROBSON}

has succeeded in this respect as, even under its competitive market benchmark, substantial classes of apparent rents would remain in the downstream entity.

There is therefore considerable uncertainty about the precise allocation of income mandated by the legislation. That uncertainty will doubtless translate into controversy and litigation. What can be said is that if the issue is resolved in a way that essentially taxes investment in innovation and in superior efficiency, the effects would be damaging to the welfare of Australians.

\section{CONCLUSIONS}

David Ricardo, who introduced the concept of rent used in modern economics, had no doubt that at least in principle, taxes on pure rents were the least distorting form of taxation. In a famous passage, ${ }^{41}$ he quotes Adam Smith's view that taxes on rents cause 'no discouragement ... to any sort of industry' and comments that 'it must be admitted that the effect of these taxes would be as Adam Smith has described.' Yet Ricardo, probably the finest analyst of tax incidence in the history of economics, opposed rent taxes. He did so because 'exclusive taxation' of those rents would have unfortunate economic consequences arising from the inherent 'risk' of that taxation.

That risk, Ricardo wrote, came from the 'indefinite nature and uncertain value' of what was being taxed which would inevitably undermine property rights. A country which depended on taxing rents, he wrote, would ultimately find itself impelled 'to adopt the Asiatic mode, and consider the government at all times, both in war and peace, the sole possessor of land, and entitled to all the rent'. ${ }^{42}$

${ }^{41}$ See Ricardo, above n 13 , ch 14.

${ }^{42}$ Carl Shoup, Ricardo on Taxation (Columbia University Press, 1960). 


\section{REVENUE ALLOCATION UNDER THE MRRT}

These difficulties have been apparent in the evolution from the original RSPT through to the MRRT. For reasons that are now well known, this has been a poor quality policy process; it has led to a tax that is substantially distorting, both in itself and through its lack of sensible integration with the tax system of the resource states. The legislation giving effect to the tax introduces new, potentially serious, distortions in its questionable treatment of the determination of the taxable income attributed to the resource. While the precise interpretation of the relevant sections is uncertain, and will undoubtedly give rise to controversy, its intent appears to be that of taxing efficiency rents, undermining the incentives for innovation.

It would have been far preferable to engage a proper policy process that cooperated with the states in placing resource taxation on a sound long term basis. That was not done, and the result is that if there is a baby in the MRRT bathwater, it does not seem to be worth saving. Rather, the right approach is to start again. 


\section{BOX A: THE IMPACT OF CAPACITY COSTS ON RENT DETERMINATION}

One traditional method for estimating resource rents in mining industries is to compute the difference between the price of the resource and the marginal costs of extraction and downstream activities. For a variety of reasons, there are considerable problems involved in using this 'net price' as a measure of resource rents. This is particularly the case when downstream activities are capacity constrained. ${ }^{43}$

This box explores the problems with this method by setting up a simple model of a competitive market of vertically integrated suppliers, who are each comprised of upstream miners and downstream infrastructure providers.

Consider the following simple setup. Time is indexed by $\mathrm{t}=$ $0,1, \ldots, \mathrm{T}$. Suppose that the marginal costs of extracting the resource are $c$. There is an initial amount of resource, $R_{0}$. The rate of extraction in each period (which will be determined endogenously) is $\mathrm{q}_{\mathrm{t}}$. The marginal costs of downstream transport and processing are $\mathrm{k}$. Let $\mathrm{K}$ be the aggregate capacity of the downstream infrastructure assets. We assume initially that this capacity is exogenous. Consumer valuation of the resource in each period is $\mathrm{U}\left(\mathrm{q}_{\mathrm{f}}\right)$. The discount factor is $\rho$.

To illustrate the issues involved and to simplify the analysis, we assume that the marginal costs of extraction and the costs of downstream processing are zero. In other words, in the absence of downstream capacity constraints, the price that the resource

\footnotetext{
${ }^{43}$ For overviews of the difficulties involved in estimating rents using the traditional method, see Jeffrey Krautkraemer, 'Non-renewable Resource Scarcity' (1998) 36 Journal of Economic Literature 2065 and John Livernois, 'On the Empirical Significance of the Hotelling Rule' (2009) 3 Review of Environmental Economics and Policy 22. For a complete analysis of the effects of capacity constraints, see Harry Campbell, 'The Effect of Capital Intensity on the Optimal Rate of Extraction of a Mineral Deposit' (1980) 13 Canadian Journal of Economics 349.
} 


\section{REVENUE ALLOCATION UNDER THE MRRT}

would sell for in a competitive market is entirely comprised of resource rents.

Let us solve for the efficient rate of extraction in this example. The problem of a central planner would be to maximise the discounted present value of the consumption benefits of the resource, subject to the resource constraint and the aggregate capacity constraint in each period. The Lagrangean equation for this problem is:

$$
L=\sum_{t=0}^{T} \rho^{t} U\left(q_{t}\right)+\mu\left[R_{0}-\sum_{t=0}^{T} q_{t}\right]+\sum_{t=0}^{T} \lambda_{t}\left[K-q_{t}\right]
$$

The multiplier $\mu$ is a measure of the (present value of) the scarcity rent of the resource. It is the value of leaving the resource in the ground today and instead consuming it tomorrow. Alternatively, if a discovery was made and the resource constraint was relaxed by one unit, then discounted utility would increase by $\$ \mu$.

The multipliers $\lambda_{t}$ are a measure of the (present value) of the return flowing to the downstream infrastructure assets as a result of capacity constraints. If the downstream capacity constraint does not bind, then $\lambda_{t}=0$ and we are back in the standard Hotelling world.

If, on the other hand, the constraint does bind, but capacity is relaxed by one unit in every period, then discounted utility would increase by $\$ \sum_{t=0}^{T} \lambda_{t}$.

The first order conditions for the problem are of the form:

$$
\rho^{t} U^{\prime}\left(q_{t}\right)=\mu+\lambda_{t}
$$

The left hand side is often used as a measure of resource scarcity rents. This is valid when there are no downstream capacity constraints. However, when $\lambda_{t}>0$, this measure will 


\section{H ERGAS AND A ROBSON}

overestimate resource rents. The result is shown diagrammatically below:

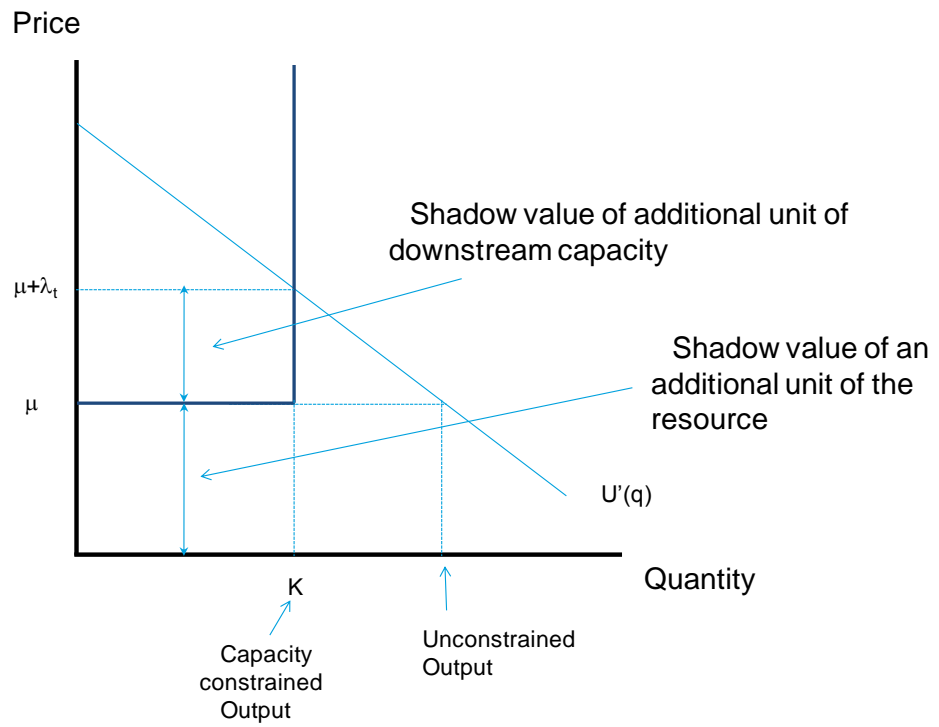

\section{Numerical Example}

Suppose $R_{0}=1000 . T=10 . \quad \rho=0.92 . \quad U(q)=q^{\alpha}, \alpha=0.8$, $\mathrm{K}=120$.

The optimal extraction path under these assumptions can be estimated easily in Excel and is shown in the figure below. Note that the capacity constraint binds in periods $t=0$ to $t=5$. After this, optimal extraction is less than capacity. 


\section{REVENUE ALLOCATION UNDER THE MRRT}

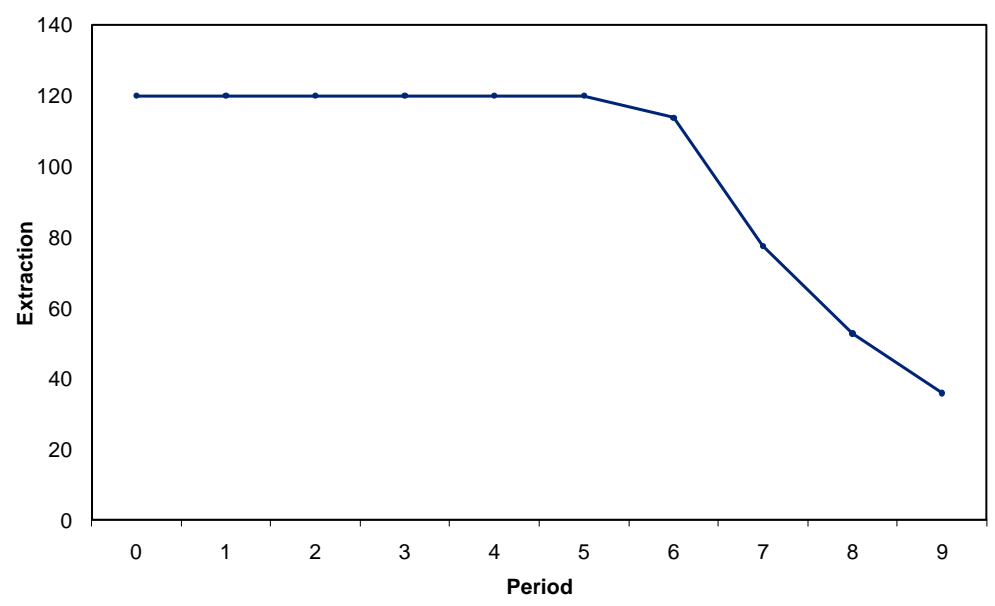

The shadow values are plotted below. In this example, failing to take into account downstream capacity constraints will result in an overestimate of resource rents by more than 50 per cent in the first period (an estimate of 0.31 in period 0 , versus a correct shadow value of 0.20 ).

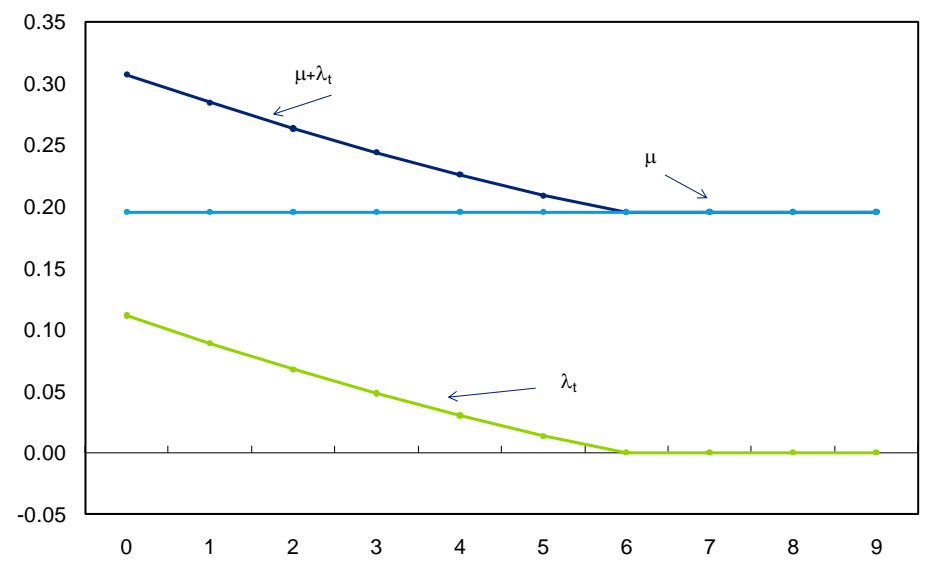




\section{BOX B: APPLYING THE SHAPLEY VALUE TO A HYPOTHETICAL MINING CASE}

Consider the following example, with ore $(\mathrm{O})$, rail $(\mathrm{R})$ and port $(\mathrm{P})$. Each input is crucial to the mining process: ore is worthless without port and rail, but obviously ore itself is a crucial input into the final output. The problem is to determine what should be the 'fair' share of the value of the final output.

Suppose that the values of each subcoalition of factors is as follows:

$$
\begin{aligned}
& \mathrm{V}(\mathrm{ORP})=40, \mathrm{~V}(\mathrm{O})=24, \mathrm{~V}(\mathrm{P})=3, \mathrm{~V}(\mathrm{R})=8 \\
& \mathrm{~V}(\mathrm{RP})=15, \mathrm{~V}(\mathrm{OP})=36, \mathrm{~V}(\mathrm{OR})=31, \mathrm{~V}(\varnothing)=0
\end{aligned}
$$

The core of this game is empty - there is no way to split the value created by the grand coalition in such a way that no single entity or subcoalition wants to deviate. However, a Shapley value can be computed that will still have the reasonable features that one would want to ascribe to an axiomatic solution.

The elements of the calculation are as follows. We first calculate all possible ways or permutations in which the grand coalition of the three factors can form. There are $\mathrm{N} !=3 !=6$ such permutations. For each permutation, we calculate the marginal contribution that each factor makes.

For example, consider the permutation OPR. O's marginal contribution is $\mathrm{V}(\mathrm{O})-(\varnothing)=24$. Next, the marginal contribution of port is $\mathrm{V}(\mathrm{OP})-\mathrm{V}(\mathrm{O})=36-24=12$. Finally, the marginal contribution of rail is $\mathrm{V}(\mathrm{OPR})-\mathrm{V}(\mathrm{OP})=40-36=4$.

These contributions produce the numbers in the first row of the table below. The same procedure is repeated for all 6 possible permutations, and then the average marginal contribution is computed for each factor, resulting in the numbers in the last row of the table below. In this example, note that ore receives slightly more than $\mathrm{V}(\mathrm{O})$, whilst port and rail 


\section{REVENUE ALLOCATION UNDER THE MRRT}

receive slightly less than $\mathrm{V}(\mathrm{P})$ and $\mathrm{V}(\mathrm{O})$ respectively. This need not always be the case.

Average Marginal Contributions - Shapley Values

\begin{tabular}{lcccc} 
& O & R & P & Total \\
\hline OPR & 24 & 4 & 12 & 40 \\
ORP & 24 & 7 & 9 & 40 \\
RPO & 25 & 8 & 7 & 40 \\
ROP & 23 & 8 & 9 & 40 \\
POR & 33 & 4 & 3 & 40 \\
PRO & 25 & 12 & 3 & 40 \\
\hline Average & 25.67 & 7.17 & 7.17 & 40 \\
\hline
\end{tabular}

